\title{
Political ecology of movement: trekking and territoriality among the Kayapó
}

\author{
Laura Zanotti ${ }^{1}$ \\ Purdue University, USA
}

\begin{abstract}
One key strand of political ecology inquiry draws attention to different scalar aspects of territorial control and environmental governance, especially as they relate to inequity, power, and marginality in the rural South. Simultaneously, in the past several decades scholars have argued for a more meaningful engagement with space and place, as global forces of capitalism and geographies of difference make and unmake places in surprising and often violent ways. In this article, I interweave political ecology and anthropology of space and place approaches to territorial practices in the Brazilian Amazon to demonstrate how multiscalar politics of territorial retention and use are layered alongside local, spatial practices. In the Brazilian Amazon, indigenous rights are closely linked to the territorial demarcation and protection of federally defined Indigenous Lands. To that end, a general pattern has been observed across Amazonia that colonization and state-making agendas regarding territorial control have coincided to an increased sedentism of indigenous peoples. This narrative elides the present and ongoing importance local ideas about territories and place have for indigenous communities. Ethnographic data from research with the Kayapó, an indigenous group in Brazil, is presented to draw attention to the complexities of the local responses to the past several decades of change that have resulted in a federally defined territorial homeland and shifting spatial practices within those lands. The Kayapó response is a particularly well-suited case study for this type of analysis, as the tribe is known ethnographically for their fissioning and trekking patterns. I show that movement, mobility, and travel still figure into everyday practices in meaningful ways. While far from homogenous, movement through the landscape is part of responding to current demands to their ways of life. I also argue that travel also affirms the Kayapó notions of knowing (kukradjà), beauty (mê), and strength (tycht).
\end{abstract}

Keywords: political ecology, Amazonia, travel, territoriality, space and place

\section{Résumé}

Un volet essentiel de l'enquête de l'écologie politique attire l'attention sur différents aspects scalaires de contrôle territorial et la gouvernance environnementale. Un accent particulier est l'inégalité, la puissance et la marginalité dans les zones rurales des pays du Sud. Simultanément, dans les dernières décennies les chercheurs ont plaidé pour un engagement plus significatif avec l'espace et le lieu, que les forces globales du capitalisme et des géographies de différence font et défont les lieux de façons surprenantes et souvent violentes. Dans cet article, je s'entremêle l'écologie politique et anthropologie de l'espace et du lieu, à des pratiques territoriales de l'Amazonie brésilienne. Je démontre comment la politique multiscalaire entourant la conservation et l'utilisation du territoire de sont posés à côté des pratiques locales et spatiales. En Amazonie brésilienne, les droits des autochtones sont étroitement liées à la délimitation et la protection des terres autochtones définis par le gouvernement fédéral territoriale. Un modèle a été observée à travers l'Amazonie la colonisation et l'agenda l'Etatique en ce qui concerne le contrôle du territoire ont coïncidé à une sédentarité accrue des peuples autochtones. Ce récit élude l'importance actuelle que des idées locales sur les territoires et le lieu ont pour les communautés autochtones. Je présente des données ethnographiques tirer avec les Kayapó, un groupe autochtone au Brésil. J'attire l'attention sur la complexité des réponses locales apportées au cours des dernières décennies du changement, qui ont abouti à une patrie territoriale définie par le gouvernement fédéral. Ils se tournent avec une stratégie 'spatiale' au sein de ces territoires. La réponse des Kayapó est une étude de cas particulièrement bien adapté pour ce type d'analyse, parce que la tribu est connue pour leur modèle de groupes sociaux fissionnant, et le trekking. Je montre que le mouvement, la mobilité, et le voyage figurent encore dans les pratiques quotidiennes de manière significative. Bien que loin d'être homogène, le mouvement à travers le paysage fait partie de la réponse aux exigences actuelles de leurs moyens de subsistance. Je soutiens aussi que le voyage affirme également les notions Kayapós du savoir (kukradjà), la beauté (mê), et la force (tycht).

Mots-clés: écologie politique, Amazonie, voyage, territorialité, l'espace et le lieu

\footnotetext{
${ }^{1}$ Dr. Laura Zanotti, Assistant Professor, Department of Anthropology, Purdue University, West Lafayette, Indiana 47907, USA. Email: lzanotti "at" purdue.edu. This work would not have been possible without the support from the residents in the Kayapó village of A’Ukre. I would also like to thank the anonymous reviewers for their constructive comments and suggestions. The Associação Floresta Protegida provided tireless help with logistics. A US NSF Doctoral Dissertation Grant funded a portion of this research.
} 


\section{Resumen}

Un punto clave del estudio de la ecología política centra la atención en los diferentes aspectos del control territorial y gobernanza ambiental, especialmente en lo referente a las desigualdades, poder y marginalidad del Sur rural. Al mismo tiempo, en las últimas décadas los académicos han abogado por una implicación más útil del espacio y el lugar, ya que las fuerzas globales del capitalismo y las geografías de las diferencias hacen y deshacen los lugares de formas sorprendentes y a menudo violentas. En este artículo, entretejo la ecología política y la antropología de los enfoques de espacio y lugar a las prácticas territoriales del Amazonas brasileño para demostrar cómo las políticas multiescala de retención y uso territorial están extendidas junto a las prácticas locales y espaciales. En el Amazonas brasileño, los derechos de los indígenas están estrechamente vinculados a la demarcación y protección territorial de las Tierras Indígenas definidas federalmente. Para tal fin, se ha observado un patrón general en todo el Amazonas que tanto las agendas de colonización y estado relacionadas con el control territorial han coincidido en un incremento del sedentarismo de los indígenas. Esta narrativa eluda la importancia que las comunidades indígenas dan a las ideas locales de territorio y lugar. Los datos etnográficos de la investigación con los Kayapó, un grupo indígena brasileño, se presentan para centrar la atención en las complejidades de las respuestas locales a las últimas décadas de cambio que han resultado en un territorio federalmente definido y un cambio en las prácticas espaciales dentro de esas tierras. La respuesta de los Kayapó es un caso práctico especialmente idóneo para este tipo de análisis, ya que la tribu se conoce etnográficamente por sus patrones de fisión y senderismo. Demuestro que el movimiento, movilidad y los recorridos siguen formando parte de las prácticas diarias de formas significativas. Si bien el movimiento a través de la selva está lejos de ser homogéneo, si que forma parte de las demandas actuales de su forma de vida. Asimismo sostengo que los recorridos también afirman las nociones de conocimientos (kukradjà), belleza (mê), y fortaleza de los Kayapó (tycht).

Palabras clave: ecología política, la Amazonia, los viajes, la territorialidad, el espacio y el lugar

\section{Introduction}

One key strand of political ecology inquiry draws attention to different scalar aspects of territorial control and environmental governance, especially as they relate to inequity, power, and marginality in the rural South (Dove 2011; Guha 2000; Peet and Watts 1996; Peluso 1998). In the past several decades scholars also have argued for a more meaningful engagement with space and place, as global forces of capitalism and geographies of difference make and unmake places in surprising and often violent ways (Escobar 2008; Harvey 1990; Peluso and Watts 2001). In this article, I interweave political ecology and anthropology of space and place approaches to territorial practices in the Brazilian Amazon, to demonstrate how multiscalar politics of territorial retention and use are layered alongside local, spatial practices. In the Brazilian Amazon, indigenous rights are closely linked to the territorial demarcation and protection of federally defined Indigenous Lands (Terras Indígenas). Within the charged context of self-determination efforts, indigenous groups have mobilized around different claims, creatively resisted and participated in global processes, and challenged the depiction of indigenous cultures as static and fixed (Robbins 2012; West 2006). At the same time local spatial practices have been impacted by these territorial politics in diverse ways. Political ecology's strength is that it is able to unpack these overlapping and concurrent processes whereby discourse and action are varied, multiple and strategic.

In so doing, I build upon social science scholarship that has recently rethought how mobility and movement inform studies of space and place (Blunt 2007; Foucault 1980; Hannerz 1997; Soja 1986; Urry 2007). Across the literature, mobility is often expressed as a direct result of the processes of globalization and neoliberalism (Castree 2006, 2008). In this context, researchers have examined different sites to analyze the rapid movement associated with international and transnational flows (Sassen 2002). Cultural geographers, for instance, use personal or fictional examples of taking a train or traveling to work in the morning as events that are illustrative of the "new" mobile world (Adey 2010; Massey 2005). Alongside urban experiences, case studies from anthropology have highlighted the historical interplay between circulations that cut across the rural-urban nexus. For example, groups that are characterized by movement-refugees, diasporic populations, migrants, and immigrants-are not only positioned in global topographies but also in longstanding, local and regional networks (Appadurai 1996). Parallel to these developments, social scientists have deepened their understanding of approaches to space and place, drawing especially upon examples of how resource-dependent and indigenous groups engage with cultural landscapes (Escobar 2001; Feld and Basso 1996; Fine-Dare and Rubenstein 2009; Gupta and Ferguson 1997). These approaches highlight that the 
analysis of movement as a contemporary, global phenomenon should also be grounded in identifying local place-making strategies within complex terrains (Low and Zuñiga 2003; Snead, Erikson and Darling 2009).

I set this analysis in Brazil among the Kayapó, an indigenous group in the Amazon region. In this article I consider Kayapó place-making practices and their disjuncture, with but inevitable emplacement alongside broader territorial concerns. The Kayapó continue trekking and travel despite several centuries of changing territorial configurations that have resulted in the current agro-industrial and conservation mosaic that characterizes the Brazilian Amazon today (Hecht 2011; Schwartzman et al. 2010). As a result, multiple and oftentimes contradictory narratives and practices dominate engagements with place. In the past several decades, the Kayapó have struggled to retain their lands and fight for territorial recognition. This has been a recurrent theme in regional, national, and even international politics. The Kayapó, who number approximately 8,000 individuals, now live in the Kayapó Indigenous Lands, which are a federally demarcated homeland set in the heavily deforested states of Pará and Mato Grosso (Figure 1). The forest and savannah habitats contained within more than 11 million hectares of the protected territory are considered vital to the different environmental services in the region (Zimmerman et al. 2001). What is noteworthy about trekking and travel among the Kayapó is that it points to indigenous notions of territorial engagement that diverge from national, conservationist, and other conceptions of the same place. Simultaneously, Kayapó movements in the landscape today reflect centuries of change as heterogeneous forms of travel have emerged over the past several decades.

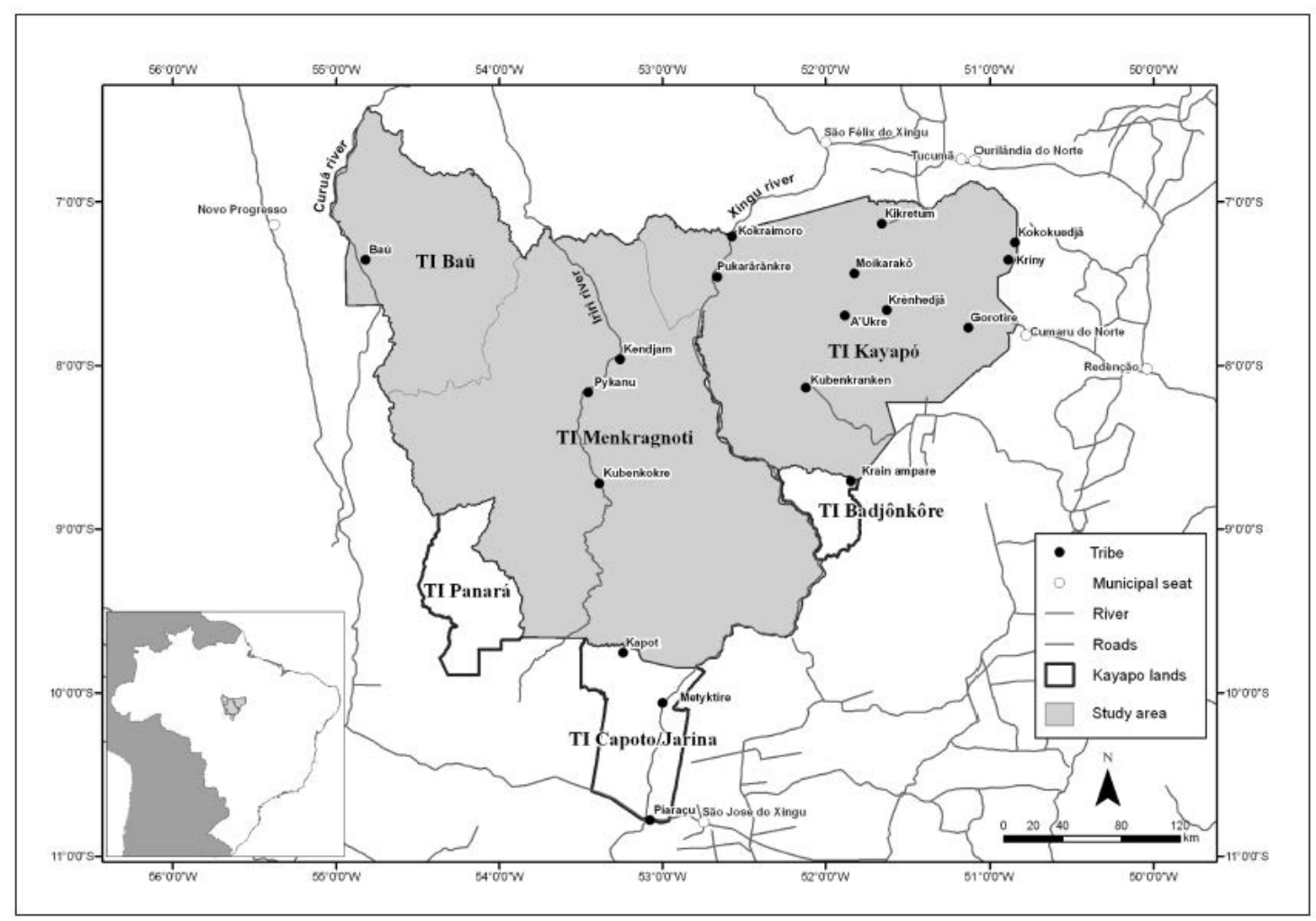

Figure 1. Kayapó Indigenous Lands in the Brazilian Amazon (outlined), and study area (shaded). Source: Louis Barbosa.

Current territorial politics have roots in historical transformations that have influenced settler and indigenous interactions since colonization. In the Amazon, scholars note that colonization and state-making agendas have coincided with an increased sedentism of indigenous peoples (Alexiades 2009). ${ }^{2}$ While this

\footnotetext{
${ }^{2}$ For example, Rival (2002:16) describes the current status of the Kayapó in the following manner: "Today, economic development has forced [the Kayapó] to give up their transhumant way of life for a more sedentary lifestyle in fixed villages and to intensify their horticultural activities, which are no longer seasonal."
} 
description broadly characterize historical transformations, it also elides indigenous practices that are still in place. For example, with contact in the early twentieth century and the subsequent rapid development of the states of Pará and Mato Grosso, the Kayapó, like many indigenous groups, were subject to bureaucratic and administrative norms enacted by the National Indian Agency (FUNAI) and were also devastated by disease, warfare, and death (Arnaud 1989; Posey 2002:20; Turner 1995a). This experience was set against the backdrop of a rapidly changing landscape, which was first dominated by rubber economies but quickly included mining, timber, and ranching enterprises (Schmink and Wood 1992). Burgeoning Amazonian markets produced many of the instant cities and roads that border, and continue to threaten, the Kayapó Lands today (Schmink and Wood 1992). Kayapó communities were resettled into different villages, aircraft landing strips were built, and FUNAI consolidated different groups in order to "pacify" indigenous peoples. This was a way to open up the region for what Fisher (1994) calls the mega-development programs that were carried out in the 1970s and 1980s. Little (2001) summarizes the experience of indigenous groups in a series of phases that have cyclically defined the Amazon region: missionary, mercantile, national developmentalism, and more recently, environmental economies (see also Rubenstein 2004). Moreover, Little (2001) argues that indigenous groups have shaped and been shaped by these diverse political economies that have at different points in history dominated the political, economic, ecological, and cultural landscape.

The expansion of markets in the Brazilian Amazon during the military regime took place alongside the formation of a robust indigenous movement, which now has a strong presence in the area (Warren and Jackson 2003). It has also coincided with the democratic turn in Latin America as well as a growing conservation movement with linked concerns of community development (West, Igoe and Brockington 2006). A little more than a decade after the 1988 Brazilian constitution was ratified, the Kayapó were able to finalize the demarcation of the majority of their homeland. ${ }^{3}$ This occurred despite many challenges that Kayapó groups continued to face, including illegal logging and mining, a frontier economy that is hostile to their ways of life, and large-scale hydrodevelopment (Diamant 2010; Turner 1995a). At the same time, Kayapó groups attracted non-governmental conservation organizations, forged celebrity alliances, and developed an aesthetic of indigenous politics that would mark their struggles in years to come (Conklin 1997; Rabben 2004; Turner 1995a). Building strong community-conservation partnerships, the Kayapó are now networked within an institutional structure that cuts across government and non-governmental organizations to develop sustainable economic programs within villages, often based on non-timber forest products but also associated with improving food security and other opportunities (such as REDD+ programs).

These events point to the complicated landscapes that indigenous groups move within today. Although the historical record and ethnographic research support the notion that indigenous concepts of territories are fluid, flexible, and overlapping and that indigenous relationships to place are inevitably marked by movement, this recognition comes at the same time that indigenous groups are mobilizing around a particular juro-legal homeland (Alexiades 2009; Fine-Dare and Rubenstein 2009; Rival 2005). It is critical to recognize that the efforts of the Brazilian government to define and demarcate Indigenous Lands, and indigenous struggles to ensure their communities have ongoing secure land tenure, all happen in a national and international context where specific types of territorialities are recognized (Stocks 2005). Within the juro-legal context of homeland demarcation it should come as no surprise that those efforts to raise awareness about threats to secure homelands draw upon the rhetoric of powerful international movements such as conservation and pan-indigenous movements (Conklin and Graham 1995). For indigenous leaders, the deployment of such narratives demonstrates a strategically cultivated register of difference and belonging based on historically charged processes of state formation, protected area demarcation, and the current conservation-development matrix in the Amazon region (Tsing 2007).

So, when in 2006 I was encouraged by community members in A'Ukre village, which is located in the northeast portion of the Kayapó Indigenous Lands, to arrange to visit the savannah, I was interested in finding out how residents engaged with the landscape today. Using the trek I took with a middle-aged Kayapó couple alongside other ethnographic data collected, in this article I consider Kayapó travels in the landscape and their correspondence with, but inevitable emplacement alongside, broader territorial concerns. While far from homogenous, movement through the landscape is part of making place, individual choices, and responses to the demands of mixed economies. It was during the trek, talking about and trying to observe

\footnotetext{
${ }^{3}$ Article 231 of the 1988 constitution specified rights indigenous groups had to their lands (See Albert 1992).
} 
the land through their eyes, that I understood that travel to Kayapó also was connected to local notions of knowing (kukradjà) and to the values of beauty (mê) and strength (tycht). ${ }^{4}$ The suggestion to travel to the savannah also threw into prominent relief the politics associated with territorial control and environmental governance in the Amazon by showing how villagers in A'Ukre, who are located in the interior of the Kayapó Lands, continued to enact out their livelihood practices and make place according to local sensibilities that have responded to decades of change. Community members I worked with were keen to note that their lands would be meaningless to them if they could not continue to "be Kayapó" in them.

I base my analysis on more than twelve months of fieldwork and subsequent visits to A'Ukre, with the most concentrated period of fieldwork taking place in 2006 and 2007. A'Ukre, a mid-sized village of approximately 370 residents, is located on the east side of the Kayapó Lands and is 45 minutes by plane from the nearest town (Figure 1). The village has roughly 38 households, a men's house, a school, a clinic, a nongovernmental organization project house, a landing strip, and a soccer field. Community members participate in different types of economies to make a living, including horticultural practices and earning cash-income. The main sources of income in the community come from governmental aid programs, salaried positions (at the school, the clinic, and leadership positions in town with non-governmental and governmental organizations), sustainable development projects, and seasonal work (Zanotti 2009). Past experience with different types of income include a community-company partnership with the UK-based cosmetic company, the Body Shop, and trying but ultimately rejecting logging (Zimmerman et al. 2001). Current projects in the area have turned more to sustainable development options through the partnership with international conservation organizations and local, indigenous non-governmental organizations such as the Associação Floresta Protegida (AFP).

A'Ukre was founded in 1979 when a faction split off from Kubenkranken, a larger savannah-based village, and then moved downriver to the current site in the neotropical forest. ${ }^{5}$ This faction from Kubenkranken initially populated A'Ukre, and later, migrations occurred from other villages within the Kayapó Lands, such as Gorotíre. In 1996, A'Ukre also experienced a fission when a faction again moved downriver to form the village of Moikarako, which is also composed of populations from Gorotíre. More recent fissions have also taken place in the past two years. A'Ukre, as a village of approximately thirty plus years, is an interesting case study to consider when examining the way movement and travel factor into the territorial politics of the Kayapó. At the time of my research, the community members in A'Ukre had already established a vast network of agricultural and forest trails. The community named and defined many of the areas around the village. Paths that led to the rivers and streams, manioc soaking areas, animal traps, bridges, canoe ports, old structures from previous rituals, and structures for camping were already present in the landscape.

In the remainder of the article, I examine how trekking and traveling act as venues for producing and practicing different types of knowledge, reflect necessary relationships that define Kayapó life, and meet economic and non-economic needs. I also show how these heterogeneous forms of trekking are part of current territorial politics. As such, I use multiple terms to discuss trekking in this article: mobility, movement, and travel. Alexiades (2009:4), drawing upon Belly and Taylor (2004), notes, "As a 'means to ends in space, 'mobility' refers to all forms of territorial movement by people." It is in this sense that I refer to mobility. Movement, on the other hand, signifies the way in which people physically, mentally, and spiritually move within different types of landscapes. I adopt a phenomenological perspective, which holds that bodies in motion are key sites "to understand[ing] place" (Cresswell 2004:33). However, I do not deny that other types of movements and sensations are also relevant (Santos-Granero 2006). Bodily movement through the landscape provides a sensate, kinesthetic, and tactile phenomenology of daily life (Heidegger

\footnotetext{
${ }^{4}$ Turner (2003) emphasizes that the Kayapó values of beauty and power are fundamentally tied to the ritual sphere. While the passing down and exhibition of beautiful names and their conferred social values are expressed in ritual and embodied in everyday practice, I also suggest that knowledge about the landscape is also captured in the concepts of beauty and strength.

${ }^{5}$ The Kayapó are known for their fissioning and trekking patterns, and the fissioning histories of Amazonian groups, like the Kayapó, have figured largely in debates among Amazonian scholars (Bamberger 1979; Gross 1975; Turner 1965, 1979). While I outlined a few different scenarios postulated about the rationale behind village fissioning in this article (See Rival 2002:16), I will note the ethnographic interest in fissioning histories among the Kayapó has resulted in a series of works that detail Kayapó movements across the landscape over time (Ewart 2003; Fisher 1991,1998; Turner 1965, 1979; Verswijver 1992b).
} 
1971; Relph 1976; Tilley 1994; Tuan 1977). In this vein, movement is an embodied practice that generates a fluid, dynamic relationship with the human and non-human aspects of the environment and is part of local ideologies in practice (Bourdieu 1990; Lefebvre 1991; Ortner 2006; Whitridge 2004). Finally, I also employ movement and travel in the way that Ingold envisions the terms, not to denote a detached observer, but to suggest the way in which inhabitants "know as they go as they journey through the world along paths of travel. . . movement is itself the inhabitant's way of knowing" (2011:154).

\section{On treks and travels}

Trekking is not the customary orienting frame used when discussing Kayapó notions of space and place. The classic way of introducing ethnographic work among the Kayapó begins not with travels, trails, or treks but with the village. ${ }^{6}$ This frame is probably used because scholars have repeatedly emphasized that for Gê and the non-Gê Bororo, "cosmological and social concepts are concretely expressed on the spatial plane, each village is the center of its own universe, relatively independent of extra-village or religious centers" (Seeger 1981:66). Indeed, many Kayapó scholars have highlighted the significance of the concentric formation of the village-plaza complex as the ultimate expression of Kayapó notions of the universe, personhood, and social organization (Lea 1986, 1992, 1995, 2001; Turner 1979, 1980, 1995b). ${ }^{7}$ Naming ceremonies and their ritual objects have often been at the heart of such inquiries, as these events and objects are passed down and performed in the pronounced features of the village layout: the plaza, the men's house, and the ring of domestic household units (Lea 1995, 2001; Turner 1980:132). Naming rituals and beautiful name recipients, moreover, are some of the ultimate expressions beauty and strength for the Kayapó.

The two major theoretical explanations proposed for Kayapó trekking and fissioning patterns analyze these practices as part of Kayapó political ideologies, or as adaptive responses to subsistence cycles and environmental constraints. For example, Werner (1983) suggests that the Kayapó trek to optimize their diet, maximize protein intake and, for males to garner prestige through hunting. Posey (2002:28) highlights that treks were critical to procuring resources necessary for ritual cycles and played a role in the "transportation of germplasm." Bamberger (1967) also points to environmental factors, such as situating villages within trekking distance of different ecotones. Turner aligns his analysis within corporate group formation where "the most important single feature of this balance is the degree of separation of men from their natal domestic group" (1966:105). The relationship between the father-in-law and son-in-law is particularly important. Sonin-laws show piaam or respect to the father-in-law by carrying out different demands that ultimately augments the father-in-law's prestige within the household and community (Turner 1966:315). Trekking that took place over the course of the year could consist of family groups, where sons-in-law were subject to fulfilling expectations of piaam. Ceremonial hunting treks that brought together men's age-grade groups also reflected these relationships (Turner 2009:372). Fisher (1991:470) rejects corporate social formation as the only explanatory factor explaining factionalism, and instead suggests that internal conflict is a result of different types of kin and non-kin relationships that follow a "transactional logic." Bamberger (1967), Posey (2002), Turner (1966), and Verswijver (1985) highlight the devastating impact disease and death have had in intragroup conflicts and fissions. They draw attention to the epidemics experienced during contact with outsiders, that heightened factionalism because accusations of sorcery resulted in-group dispersal (Posey 2002:23).

Instead of envisioning trekking as peripheral to the village-plaza complex, central to political ideologies, or constrained by environmental adaptations, in this article I suggest that trekking for current Kayapó communities reflects demands of mixed market economies, offers a way to continue to make place in a charged region where land and territory are often in question, and serves as a stimulus to knowledge creation and transmission. Moreover, in arguing that trekking is an activity that links human and non-human actors together, I go beyond a political analysis of trekking patterns to show that kinship and corporate groups are not the only relationships that define an individual's interaction with landscape. This echoes

\footnotetext{
6 The Kayapó's spatial sphere is based on the symbolically important concept of a circle and includes horizontal and vertical spatial zones. The vertical aspect of Kayapó villages is an east-west trajectory modeled after the sun's path (Turner 1995b:162). Horizontal space is more elaborated in a "series of concentric circles" that spatially defines different socioeconomic zones (Turner 1995b:162).

${ }^{7}$ I am drawing on Lefebvre's (1991) concept of lived space as outlined by Soja (1996) and Kahn (2000).
} 
recent research in other contexts that have emphasized personal experience, gendered identities, and situated practice as relevant to knowledge acquisition (Lauer and Aswani 2009; Spoon 2011). Using a daylong trek with Paolo and Iredja, a Kayapó couple, as an illustrative example, the next portion of the article explores the varied ways in which movement is practiced among the Kayapó. ${ }^{8}$ For individuals like Paolo and Iredja, knowing is intimately connected to human-human and human-nonhuman interactions, sensate and experiential facets of being-in-place, individual memories about a particular locale, remembered stories that animate the landscape, mythic events that connect individuals through time and space as well as new demands of economic life. I touch upon each of these below as I relay the trek we took that day and later elaborate on their broader applications.

The morning of the trek, I sidestepped sleeping dogs and walked under mango trees to reach Paolo and Iredja's house. Weeks earlier, as Iredja tended a small fire in her kitchen hut to make coffee, she had expressed an interest in trekking to the savannah. Iredja noted that she wanted to harvest some medicinal roots, or "women's medicine", and collect parakeets' eggs to raise the young birds as her own. The parakeet feathers, she said, are used in many different festivals and are important ritual components of ceremonial dress. Paolo, her husband, noted another reason why he wanted to go. Their eldest daughter would soon have her first child, his first grandchild, and Paolo wanted to make a sling for her. Crafting and weaving this type of sling is a male task in Kayapó communities, and it requires the fibers from the savannah-based burití palm (Mauritia flexuosa). For him, the trek was a reflection of his growing family and the passage into an important life stage for his daughter, Iredja, and himself, one that would be symbolized by the collection of fibers soon to be wrought into a sling.

The hike that we were undertaking, the passage from the forested village landscape to the savannah, is particularly striking as it covers various threatened and diverse habitats in the Central Amazon region. "We know many things in the savannah" one of the leaders in the village of A'Ukre told me, since many "old villages," now abandoned, are there, some of which Paolo would gesture toward as we made our trek that day. The savannah is where the Kayapó used to live long ago, Paolo said. Indeed, Kayapó groups have long depended on different ecotones and habitats for their livelihoods, a practice that is supported in myths and oral histories and is still visible in current practices (see Posey 2002).

A'Ukre, as a relatively new village in the Kayapó Lands, was founded not far from the savannah or kapôt. Some of the young men I interviewed before I left noted that they could get to the edge of the savannah in two hours time, if they went quickly. Once you were there, you could trek for hours, depending on what you were looking for. Burití was easy to find, I was told. We would need to watch out for animals, but the savannah had been recently burned by some of the men in the village. Paolo said the "Kayapó always burn the land this time of year" so you could "see better." Maybe we would be able to find some parakeet eggs, another consultant offered. Since the sun was setting early in the evenings, Paolo, Iredja, and I had to plan our departure in advance so that we would not return in the dark.

By 6:30 a.m., the three of us had set foot on the appropriate trail with a strong, relaxed pace. Paolo had on a green shirt and yellow shorts and carried his shotgun. Iredja, in an orange cotton dress, placed a basket on her back and came with some dried manioc, a two-liter coke bottle filled with water, and a machete. As we moved beyond the village, Paolo drew my attention to the varied way the path to the savannah was embedded in the everyday practices of villagers' lives. Quickly moving beyond the horticultural-field matrix of tall banana trees and pokey manioc plants, he led us to a well-worn log, serving as a bridge. The bridge brought us across a steep ravine and as we pushed forward Paolo pointed out a vacated fish encampment and a sagging, tilted wood grill. This spot, Paolo relayed, was a popular resting point between the savannah and home to cook recently caught fish.

After two hours of winding our way through the neotropical forest area, we reached the top of a hill and saw the savannah unfurl as a charred, sepia-toned landscape. Large, iridescent insects fluttered beneath a dry, blue sky. Making sure it was okay to move on after the steep climb, we pressed forward. I focused my eyes on two or three well-defined trails that cut snaking lines in the freshly burned area, which, Paolo told me, led to a variety of areas: harvest locations for different resources, overnight camping spots, trails to other villages, and locations to scout for parakeet clutches (Figure 2). As we walked, Paolo told many stories, which covered topics such as trekking, harvesting, intra-kin relationships, violence, tragedy, and intra-tribal

${ }^{8}$ All names presented are pseudonyms. 
warfare. "Over here is an old cemetery; have you heard about it?" Paolo asked. He showed me where the path snaked beyond where we were headed and said that it went to a famous spot on the river that is known for plenty of fish. It is also the spot of a bloody fight between the Xikrin Kayapó and the Kayapó, but Paolo was quick to note that Kayapó communities do not fight like that anymore. "And have you seen this old village here? There are old villages and caves that are important to us." In the middle of the trek, we stopped at a frequently used campsite and searched for water to drink and bathe in. The stream was dried up. Iredja collected some orange seeds to later make handicrafts with, and Paolo listened for game animals (Figure 3).

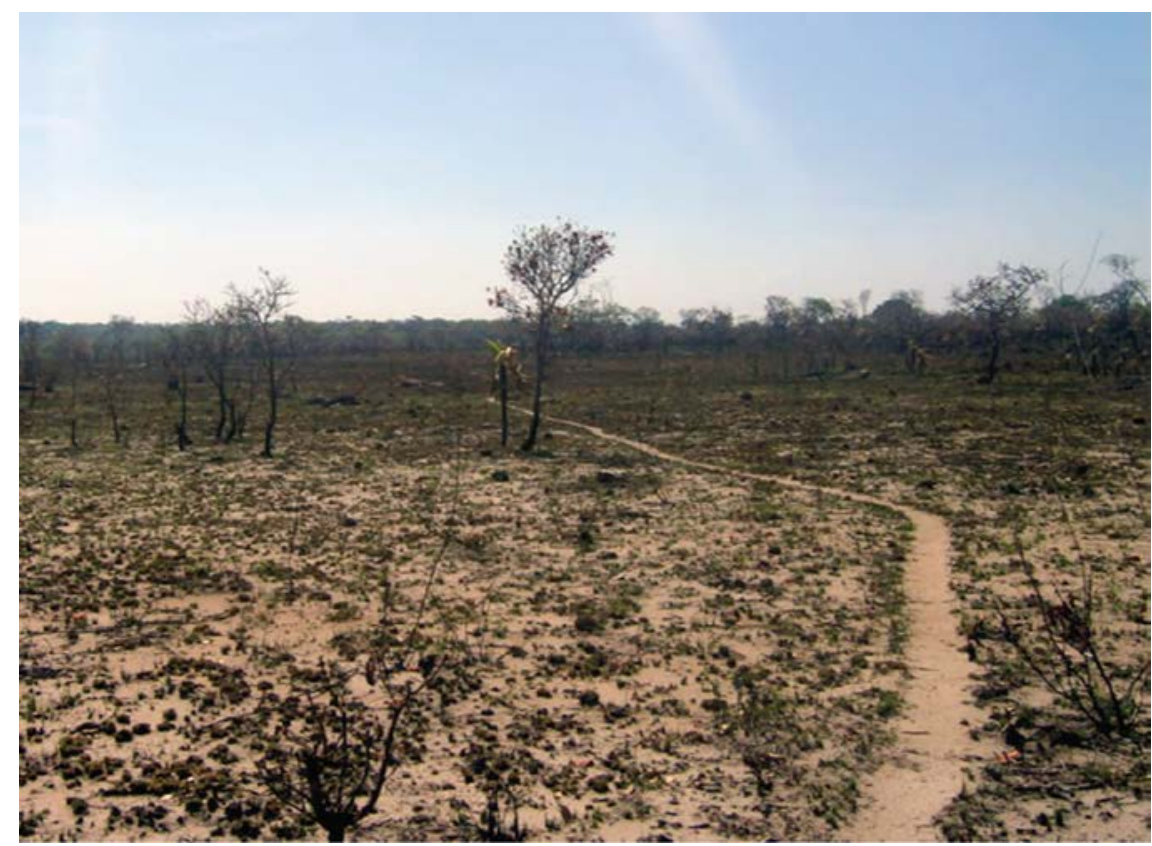

Figure 2. Photograph of recently burned savannah. Note trails present. Source: L. Zanotti.

Circling our way back to the forest trail, we stopped to harvest the burití and for Iredja to collect some roots for medicinal purposes. Paolo shuttled between topics now, discussing one of the old founders of A'Ukre, recently passed, and the various savannah treks that the chief had undertaken. The chief had been especially adept at navigating the landscape, and the loss of him and his knowledge, Paolo noted, was felt by all. At the end of this conversation, Paolo said he was telling me the history, or kukradjà (knowledge), of the Kayapó. With the long, green poles of the burití slung over their shoulders, Iredja, Paolo, and I headed back to A'Ukre. When we arrived at A'Ukre's familiar landing strip hours later, I quickly took a bath in the river in the pre-dusk hours of the evening. A man of a younger age grade, Rodolfo, stopped me. "Where have you been today?" he asked. "The savannah," I replied. "Good," he said. "You saw the savannah. Now you are beginning to know."

\section{A political ecology of movement and travel}

The trek that Paolo, Iredja, and I took evokes several aspects of travel, movement, and mobility among the Kayapó. Even though A'Ukre was formed only in the late 1970s, networks of trails connect the community to other historically salient places within the landscape. These places are part of recent events in the Kayapó's history that many still remember. While on the trek, Paolo emphasized these connections by discussing several locations within the landscape: the abandoned cemetery that was once, according to Paolo, part of an "old" village in the savannah, the extensive treks that the founder of A'Ukre would take in this savannah area, and the scenes of intra-tribal warfare, not in the immediate area, but close enough for Paolo to remember and tell such histories. 


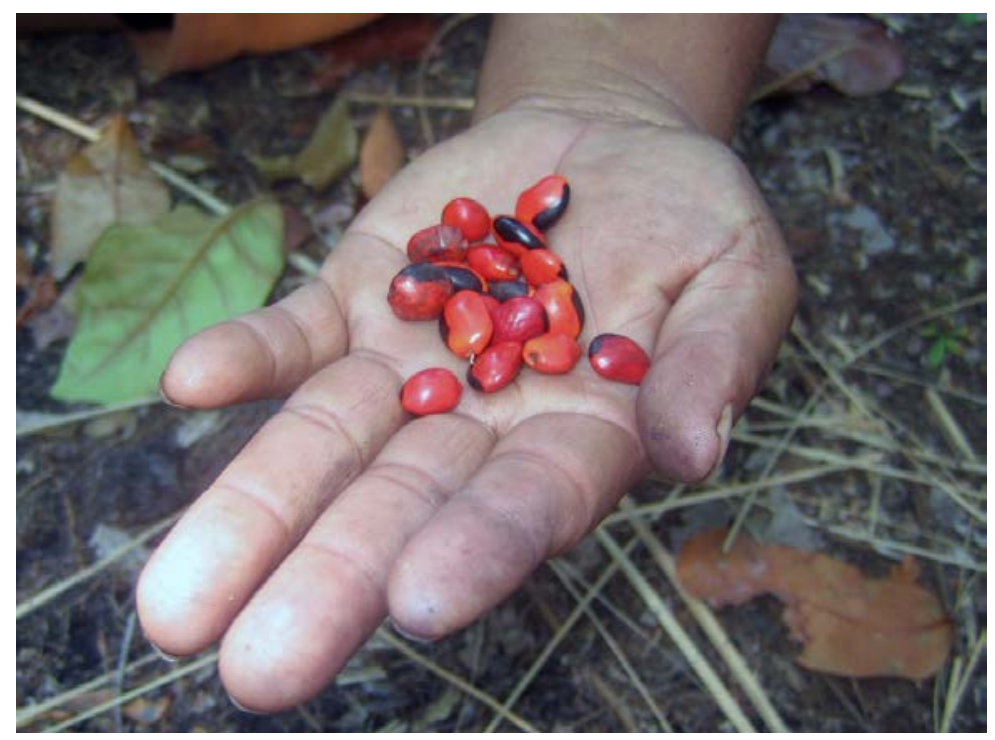

Figure 3. Photograph of seeds collected. Source: L. Zanotti.

Verswijver (1992b), when discussing different toponyms among the Kayapó, briefly notes a similar tendency toward marking the landscape with historical events. Likewise, Fernando Santos-Granero (1998:130-131) indicates that the walks he made with the Yanesha often combined personal, historical, and mythical elements, thus inscribing history within the landscape. While Santos-Granero (1998) labels these elements "topograms" to reflect their applicability to protowriting systems, others also have documented the way in which moving through the landscape enlivens historical moments (Hirsch and O'Hanlon 1995; Schama 1995). For example, Mark Nuttall, when working with Inuit groups, prescribes the term "memoryscapes" to reflect the way in which "persons, community, and landscape and the contemporary, historical, and mythical activities, events and stories that invest the environment with meaning" are linked (1998:125). And Aporta (2004:11), also working in the Arctic, suggests that routes are a part of "courses that remain and evolve in the memoryscapes of the people" and that "trails refers to the physical manifestation of routes."

Similarly, trekking for Paolo and Iredja inscribed the physical environment with their own understanding of the history of the Kayapó and provided a context for remembering and retelling "transformative" events and mythical moments that are still shared. The stories recounted by Paolo demonstrate how the act of trekking served to reflect on historical and mythic occurrences in the landscape. It was also a way to establish his knowledge about the area as well as the way in which residents of A'Ukre connected new or "alien" spaces to familiar ones through trail-making, practice, and storytelling (Feather 2009:70; Santos-Granero 1998; Turner 1980). The trails from A'Ukre that Paolo, Iredja, and I took can be considered the material reflections of different routes or "memoryscapes." For Paolo, trekking served as a way to access these routes, where, for instance, he could recount events and identify landscape elements that are relevant to the Kayapó's history he is familiar with. Additionally, repeated visits or the use of the savannah by villagers in A'Ukre, such as the former chief's treks, also serve to inscribe the landscape with new histories and memories that the current generation can call upon. Individual treks and the retelling of particular stories, although part of collective histories, thus continually shape routes over time and space.

Not surprisingly, some of the most vivid memories recounted to me during fieldwork were similar to Paolo's stories of migration and warfare among Kayapó groups during pacification efforts. According to respondents, extensive trekking on trails served as a method by which leaders scouted for new village sites and eventually created intensely familiar places_villages like A'Ukre-that enable communities to continue daily and ceremonial practices. Respondents noted that today, treks by foot, canoe, air, or other mechanisms of travel still provide valuable information to Kayapó leaders and residents about resource availability, 
features that would point to potential village sites, or general knowledge that could be strategically used in political contexts. As one chief noted, he enjoyed immensely the flights over the territory because he could "see" better and "remember" places for future use. As already mentioned, A'Ukre has fissioned twice since it first was founded, and the leaders' ability to discern new sites of occupation rests on trekking on land and water to find areas that would make "good" village sites. All of this hard work does not always pan out as expected: in the case of the first split from A'Ukre to make Moikarako, the first site of the village proved to be inadequate, and the villagers subsequently had to move it. At the same time, the chief I talked with championed flights for another reason. Flights over the territory could identify any border incursions or illegal activities, such as mining, that were taking place on their lands.

Paolo's reference to a former chief in the village while we were trekking was significant. According to respondents, leaders still need to possess extensive knowledge of the landscape, which refers not only to the biotic components of the environment and the current requisite knowledge connected to the political economy of managing a large protected area but also to knowledge associated with historical events and myths. Paolo echoed this sentiment as he admired the former chief of A'Ukre's familiarity with the landscape. Indeed, one of the complaints from many of the elders in the community of A'Ukre was that younger generations do not "know the land well" (nho pyka mari tycht) in the same way as they and their ancestors did through extensive and long treks on foot. Other ethnographers have reported the same. Werner (1983) notes that different types of treks on foot that the Kayapó undertook as a group have declined since the 1970s. Bamberger observed:

Whatever wanderlust may once have motivated movements among the Kayapó (and perhaps other Gê groups), it is important to note that today, the seasonal dislocations of the Kayapó would rarely place much distance between village and trekking camps. . . (1979:130)

The Kayapó were formerly semi-nomadic, and treks were undertaken by matri-uxorilocal household groups (women and children included), age grade bands, and men's groups (tchêt) and could last for several months (Bamberger 1979; Werner 1983). Longer-term, seasonal treks could result in permanent group fissions, but impermanent ceremonial treks, in general, divided the community for only short periods of time (Turner 1979; Verswijver 1992b). Although this might mean that group mobility has declined and that the Kayapó are no longer as fragmented, mobile, or dispersed as they were, it does not mean that the importance of travel, mobility, and trekking has also declined. Increased sedentism does not necessarily equate to notions of permanence.

For example, respondents reported several types of treks that are still currently practiced in addition to those already mentioned:

(1) Travels by plane or river to visit other villages or towns for ceremonial, personal, medical, economic, recreational, or political reasons;

(2) ceremonial hunting and fishing treks for nomination rituals that can last from one week to a month via foot or canoe;

(3) ceremonial treks to the savannah to harvest burití and other resources;

(4) fishing treks during the wet season;

(5) sporadic household treks to gather hard to find but often used resources that are not close to the village, which can be daylong treks or longer;

(6) seasonal treks to harvest Brazil nuts (Bertholletia excelsa), when applicable, when Brazil nut sustainable development projects are under way (Burke 2012);

(7) routine visits to the field-forest mosaic near the village for daily subsistence, ceremonial, and economic purposes;

(8) purposive visits to the forest for different ceremonial rites of passage or knowledge acquisition (e.g., the wasp ritual); and

(9) visits to the area just beyond the household backyards and river for personal reasons. 
The younger generation I talked with emphasized that they were learning the land, and even though they stayed "closer to home" than the elders did, it was simply because that is how the "Kayapó were today." That is, they did not need to move their homes constantly, because the period of warfare and danger that many of their grandparents knew was over. Many of the younger men and women I interviewed (twenty to thirty years old) were born in A'Ukre, or came there with their families to find work or to be closer to relatives, or enjoyed having services (health and education) for themselves and their children. Knowing the land well, to them, meant that they could provide food for their families, become successful sponsors of naming ceremonies, participate in sustainable development projects, and potentially be in future leadership positions. Furthermore, the majority of younger men in the ages from twenty to thirty were not only in the process of building families and learning specific subsistence skillsets, they were also eager to take advantage of opportunities to practice their Portuguese, visit the town, and participate in political gatherings. One consultant mentioned that he thought that Portuguese is important for the next generation, and learning to understand Brazilian society was key for the future. "We will always need to defend our land," he said, "and our young generations will help us do that." Another noted that meat from the forest sustained their communities in ways store-bought meat could not. He noted, "If we end the forests then where are we going to hunt? The white man is different. The white man cuts down the forest to grow grass just for himself but the indigenous people hunt in the forest."

The elders I interviewed also emphasized that travel via treks on foot, canoe travel, flights, and other village visits and explorations are ways in which they and others remain active in knowing their land. Rabben concurs, "Thus the Kayapó have continued traditional war-making, raiding, and trekking through their own distinctive brand of international diplomacy, traveling to the global North to gain allies at the highest levels, financial support, and prestige goods to show the folks back home" (2004:60). During fieldwork, I repeatedly witnessed the same: the use of river travel, flights, seasonal trekking, and daily walks as part of everyday movement through, across, within, and over the landscape. Treks offer the opportunity for individuals to contribute to and recall routes while at the same time providing the context in which to gather experiential knowledge. This knowledge about different locales in the landscape is used in order to meet current livelihood needs of a mixed economy, as sustainable development and other economies are practiced alongside subsistence ones.

What this also means is that on a daily basis, the bureaucratization and demarcation of the territory has brought with it frequent flights sponsored by federal institutions or regionally governed organizations (e.g., The National Indian Foundation [FUNAI], health, or environmental NGOs). With transportation services such as motors, gasoline, and airplanes, the majority of community members travel outside the village. Most community members interviewed reported they left the village for town at least once. Individuals in A'Ukre (men and women) mostly frequent went to towns on the border of the territory. Community members who currently hold or previously held governmental or non-governmental positions often travel more than others in order to attend conferences, courses, or training in nearby towns. Chiefs and their associated warriors also travel more extensively for political meetings in larger cities like Altamira, Brasília, and Marabá, and some chiefs, including those from other villages, travel internationally to places like Mexico, France, the United States, and the United Kingdom.

Other types of domestic travel include travel for economic (selling goods or spending money), protest, or cultural purposes (e.g., handicraft demonstrations). Finally, intervillage traveling also occurs on a fairly regular basis as individuals visit family members, participate in festivals, or play soccer. During fieldwork, villagers routinely commented on this type of travel. One consultant noted, "Sister-in-law, we are going to another village for a ceremony. Marcy has only seen this village and wants to see another. We travel the day after you leave. We will be back by the time you get back." In another context, I would hear, "The downriver village is coming today. We have invited them to play soccer. There will be a tournament." These comments are representative of some of the types of travel that dominate the present-day village landscape.

Trekking also demonstrates how movement through the landscape links individuals to place, despite individual mobility between and among villages. Our trek to the savannah represents this tense and complex "terrain of personal biography" embedded in landscapes (Tsing 2005:xi). Paolo and Iredja had not lived in A'Ukre long. They had moved to the village a few years earlier from another village in the Kayapó Lands. The couple had kin-ties to different individuals in A'Ukre, so they had decided to live there. This did not preclude Paolo or Iredja from "knowing" the landscape surrounding the village, and this certainly was not the 
first time they had made the trek to the savannah. I had been with Iredja to her garden several times and knew that Paolo was known as a competent hunter and fisher. The stories engendered by particular landscape features for Paolo not only served to emplace A'Ukre within broader notions of Kayapó territoriality and place but also served as a means for Paolo and Iredja to demonstrate their knowledge through engaging with the landscape while moving through it. Recounting these events connected Paolo and Iredja to past and present Kayapó histories of trekking and travel as well as their own personal biographies and experiential knowledge of place. Thus, although Paolo and Iredja were not originally from A'Ukre, trekking the land joined them to A'Ukre's landscape in a way that incorporated movement and the demands of current Kayapó livelihoods into an understanding of place.

I also take the trek that Paolo, Iredja, and I undertook to be a lived space as individuals travel on trails on a routine, seasonal, and task-specific basis (Lefebvre 1991). Lived space produces taskscapes, or landscapes populated by activity-based undertakings that define daily life. In a trek Rival (2002) made with the Huaroani, an Ecuadorian indigenous group, she noted the everyday acts that maintain and create the local landscape: "Walkers keep [these] paths open through many small and careful gestures, such as the picking up of a thorny leaf fallen during the night, the breaking of bending branches, or the cutting of invasive weeds." Routinized "careful" gestures along pathways, Rival (2002) argues, are ways of knowing the landscape, the self, and others through bodily movement and action. Ingold suggests that these careful gestures and the "array of related activities" undertaken in a landscape constitute taskscapes and that "the forms of the taskscape, like those of music, come into being through movement" (1993b:158,161).

From the way in which Paolo and Iredja talked about the land, it was clear to me that the trail we were taking was a well-known but intermittently used trail near A'Ukre. Beyond the visible demarcation of a trail in the forest and savannah, several features we encountered during our trek indicated past use for task-related activities: the abandoned fishing grill, the logs that served as bridges, the spot that Paolo and Iredja knew of to rest, and the recently burned savannah landscape. From Paolo and Iredja and other interviews I conducted in the village, I knew this route was the one that community members took to collect burití fibers used in a series of woven objects (for example, ritual costumes, slings, baskets), to connect to a fishing site sometimes used for ceremonial purposes, and to collect other savannah-based resources. For example, João, a 25-yearold politically active male in the community, said about his recent trip to the savannah:

I was collecting burití for the [naming ceremony] in the savannah. I saw a tapir not far off and thought I might want to go hunt it. I then thought to myself, who will harvest this burití for [the naming ceremony] if I go hunt? I decided to continue to harvest the buriti and return to the village.

An elder woman in the village had talked with me the day before I left and noted that a fruit only found in the savannah might be ripe at this time. "I am old and my feet are bad," she said, "and I cannot go [to the savannah]. But you can. Pick [fruit] for me and bring it back." The following excerpt from my field notes shows another example of moving through the landscape. ${ }^{9}$

Marcos and Kakrit continued on [the trail] and we stopped to rest on a thin log. . . "There used to be old fields, but they are now all overgrown," Marcos said, "and it was here that a researcher found a large mahogany tree and would not let the loggers cut it down." We proceeded through the closed canopy forest toward a small, sloping ravine littered with decaying branches, filled with thick mud and piled with leaves. This was the beginning of a trail, I was told, that led to a mud lick. Several footprints of white-lipped peccary, collared peccary, tapir, and deer were scattered around the area. Kakrit spotted a gourd hanging from a tree. "Take it back to your [friend's] house and give it to her for her child." he said. "Say you found it here." We cleaned the mud off the gourd, which was yellow-green, leathery smooth and hard.

Similarly, Paolo and Iredja seemed to know what they wanted to scout for and harvest in the savannah, were familiar with the spots where we rested, and were familiar with spots they pointed out as frequently used areas surrounding the village. At the same time, Paolo and Iredja noted different reasons for

\footnotetext{
${ }^{9}$ All direct quotations presented in field note excerpts are paraphrased.
} 
wanting to go to the savannah that day. Iredja had remarked that she wanted to collect "women's medicine" and some parakeet clutches if she was able to find them. Paolo was interested in collecting burití. While in the savannah, we did both. We did not find any parakeet clutches; however, we encountered some orange seeds that Iredja wanted to make handicrafts out of for sale. On the way back to the village, we also stopped so Paolo could harvest some bark for medicinal purposes. As other Kayapó scholars have also recognized, when the Kayapó (men or women) go trekking, hunting, or gathering, they are prepared for all kinds of encounters. Therefore, terms such as "ba ma tem," roughly translated as "I am going for a walk," are used, instead of describing a specific task, such as hunting. The multiplicity of tasks undertaken by Paolo and Iredja that day reflects the mixed economies of current Kayapó communities, which demand different types of movements within and across the landscape. In addition to subsistence practices, the tasks performed by Paolo and Iredja on our daylong savannah trek demonstrate the value of ceremonial, medicinal, and marketbased harvests undertaken while trekking.

These examples illustrate the way in which knowledge is expressed, experimented with, and acquired as one routinely moves through the landscape. Examples described above depict how encounters with resources, such as the gourd, provide opportunistic moments for harvests. Indeed, on a routine basis, these daily leisure and subsistence activities dictate micro- and macro-movements within the landscape. Daily treks provide a social space in which to carry out tasks related to subsistence, ceremonial, leisure, or market-based activities with others, a material space to learn desired skillsets, a cognitive space to "know the land," and an embodied space where movement is linked to meaning, being, and living. Movement through and within the plaza-village area and the surrounding environs spatially maps out certain social codes through correlating different social networks to the mobile, materio-spatial world of subsistence, market, leisure, and ceremony.

These tasks also demonstrate the knowledge required to identify, locate, and harvest resources and the way in which that knowledge is tied to values of beauty and strength. Among the many community members I interviewed, the accrual of knowledge over time regarding everyday gender-specific activities, ceremonial events, market-based or job-related tasks, and other practices that mark daily life was considered part of the expression of being beautiful and strong. Ideally, a certain amount of knowledge and a set of tasks were required by the time an individual had his or her first child, consultants reported, knowledge which was among the many aspects of being Kayapó. Knowledge acquisition and transmission among the Kayapó occur in various ways, through listening, seeing, practice, and different mentor-apprentice relationships that cut across social soldarities (also see Murphy 2004; Turner 1980, 1995b; Verswijver 1992a:19). Trekking constitutes a practice in which individuals accumulate and express their knowledge. Learning, then, "is seen as something that takes place in action and interaction, within a social and spatial context (often in spite of teaching)" (Murphy 2004:7). Countless examples were relayed to me to express the value of mastery over different practices that required knowledge of the land and certain skillsets. For example, during a fishing expedition several kilometers from the village, one middle-aged man reflected, "You see that young boy over there? He already knows how to fish well. He is probably going to be strong when he gets older. He is so young but already knows the ways of [poison fishing] already. I hope my son will know well too."

In other words, enacting different activities and moving through the landscape to do so provides a context for corporeal ways of knowing that rely on experiential knowledge built upon multiple sensory experiences. As Nadasdy counsels, "knowledge is not really knowledge at all," but "a way of life" (2004:121), or according to Ingold (1993a:23), a way of being in the world. The short conversation I had after bathing after the trek reflects this notion that seeing and experiencing are fundamental to knowing. After asking me where I had been that day, Rodolfo was quick to note that because I "saw" the savannah, I was "beginning to know." Here, Rodolfo used the Kayapó term mari, or "know," which is different from kukradjá or the summation of Kayapó knowledge. Mari, as Turner (1995b:153) expounds, is a word that underscores a particular aspect of knowledge acquisition-listening and hearing. Nevertheless, in this context, the word was also being used in a way that denoted understanding more closely related to the "active form of knowing" through seeing (Turner 1995b:153). Rodolfo was not the only one to comment to me that I was beginning to "know" after observing or participating in an activity. These ongoing comments made to me by villagers while I was in A'Ukre as well as casual conversations with community experts suggest that knowing is closely tied to experiential knowledge acquired over a lifetime.

The trek Paolo, Iredja and I took as well as many of the individuals I spoke with during my time with them constantly reminded me that it is important to keep in mind the way in which political, economic, 
cultural, social, ecological, and historical transformations have impacted Kayapó livelihoods. Conversations also pointed to the ongoing importance of a large territorial expanse for present and future generations. Describing indigenous groups as "increasingly sedentary" points to these territorial politics that are tied to state agendas but may not reflect everyday practices. Continuing to pay attention to travel and movement in individual acts will help in discerning agentive ways in which indigenous peoples continue to practice their diverse ways of life in the context of territorial politics that is tied to state-led and conservationist agendas. Paolo and Iredja's trek is just one manifestation of the way in which a family who has recently moved to a thirty-year-old village site makes use of and finds meaningful activities by trekking in the landscape- treks that, as emphasized above, crisscross personal biographies, historical events, and past manipulations to the landscape. I have also suggested that these different forms of mobility express different environment and social relationships.

\section{Conclusion}

Although movement and mobility are certainly not new in the ethnographic literature, I have responded to the call made by social scientists to provide a more fine-grained analysis of the role they play in contemporary indigenous lifeways. In so doing, I have stitched local place-making concerns together with a political ecology approach that is attentive to broader territorial politics (Urry 2007). Especially within the context of indigenous rights efforts, protected area demarcation, and the circulation of indigenous leaders on the world stage, the local practices that connect individuals to places are inevitably emplaced in charged landscapes. Over the past 200 years, Kayapó communities have undergone a dramatic change from savannah-based semi-nomadism to living in villages in a federally protected reserve. Where these changes have been described as increased sedentism and decreased trekking, I suggest that such depictions of current Kayapó livelihoods conceal the fact that movement and mobility, in different ways, still play a role in everyday practices.

Understanding the political, economic, and cultural forces that impact the Kayapó today is impossible without addressing the ongoing importance that trekking and travels have for individuals and communities. The relationship the residents of A'Ukre have with trekking is a complex assemblage of local place-making practices, topographical memories, and historical events that are unavoidably connected to juro-legal territorial formation. Significant changes in everyday lives include the incorporation of cities and towns as places in which Kayapó frequently circulate, transportation and communication efforts as key to territorial protection and the creation of new village sites, and travel for reasons that go beyond ideological and adaptive purposes. Moreover, I anticipate that increasing engagements with multimedia and digital technologies will also impact the way in which community members move within virtual, real, and imagined spaces in the future. At the same time, threats to their territory, such as the Belo Monte dam, will continue to require that communities like A'Ukre politically articulate their ties to place and fight for the retention of their territories.

Trekking remains fundamental to the production and habitation of place and the acquisition of knowledge. The historic, semi-nomadic patterns of the Kayapó that were characterized by different kinds of short- and long-term fissioning are still present in villages like A'Ukre. Its formation was the result of a fission in the 1970s and whose creation has also resulted in several more fissioned villages. Village formation within the territorial reserve is still the result of scouting for sites, now by plane and canoe as well as by foot. The trails established as part of the village space remain important reminders of the way in which travels divide and connect spaces over time. Moreover, although the Kayapó have decreased lengthy treks on foot, other types of movements have taken their place, including shorter treks and other types of travel (canoes, airline flights), which have arguably increased the distance, if not the amount traveled. Different venues (trails or pry) to enact treks still call upon historical and mythical elements in the landscape as well as individual memories. Villages like A'Ukre establish continuity, albeit a heterogeneous, in the landscape through the unending transformation of unfamiliar elements into familiar ones.

Where daily, seasonal, and intermittent treks might appear as micro-movements within the landscape that establish intimate connections to place over time, trekking is an activity in which individual movements through the landscape connect with broader group mobilities, personal biographies, and localized stories. Moreover, the importance of travel and knowing the land well for leaders and residents has not diminished post-contact. Although extensive treks on foot may have declined among the Kayapó, trekking still takes 
place and is valued as a source of knowledge. Ewart's observation that "villages are generated by the lived actions of people" seems relevant to this case (2003:262). In accounting for the importance of trails maintained around and beyond village centers, the lived practices of community members position village spaces not only within the central plaza complex but also within individual experience. I also have suggested that trekking contributes to the acquisition, expression, and recollection of different types of knowledge associated with the Kayapó values of beauty and strength. Taskscapes, or the embodied practice of moving through and within landscapes, are created through the repetitive array of activities undertaken in an area. It is a culmination of these activities over time and of the knowledge associated with them that actors embody the values of being beautiful and strong as they move through various life stages. Moreover, the sociality of these landscapes, either in real time or through accessing different routes, links previous and present generations together across a volatile history marked by fragmentation and consolidation.

Boundary marking serves to remind us that federal territories are actively constructed and are continually made and remade. Demarcated landscapes do not always reflect indigenous notions of territory or place and are often the outcome of multiple processes: colonial histories, state-making practices, conservation strategies, and local territorialities. Certainly, the "novel social context" of global environmental processes offers a revisionary moment for anthropologists and other social scientists to reexamine mobility and movement (Alexiades 2009:26; Urry 2007). Here, a focus on trekking serves to spiral the ethnographic gaze outward to look at how making place is tied to uneven, power-laden landscapes in dynamic locales in the global South (Naughton-Treves, Holland, and Brandon 2005). This type of approach builds upon scholarship that attempts to move away from tying indigenous groups to persistent narratives that portray the groups as static and sedentary (Tsing 2003). As development plans and adverse environmental changes continue to threaten local livelihoods, keeping a historical political economic perspective paired with the everyday practices of the Kayapó in view is critical. These perspectives are key to understanding local spatial practices and their importance in self-determination efforts and issues related to territorial control.

\section{References}

Adey, P. 2010. Mobility. London: Routledge.

Albert, B. 1992. Indian lands, environmental policy and military geopolitics in the development of the Brazilian Amazon: the case of the Yanomami. Development and Change 23: 35-70.

Alexiades, M.N. 2009. Mobility and migration in Indigenous Amazonia: contemporary ethnoecological perspectives - an introduction. In M.N. Alexiades (ed.) Mobility and migration in Indigenous Amazonia: contemporary ethnoecological perspectives. New York: Bergham Books. Pp. 1-46.

Appadurai, A. 1996. Modernity at large: cultural dimensions of globalization. Minneapolis, MN: University of Minnesota Press.

Aporta, C. 2004. Routes, trails and tracks: trail breaking among the Inuit of Igloolik. Études/Inuit/Studies 28(2):9-38.

Arnaud, E. 1989. O Índio e a expansão nacional. Belém: CEJUP.

Bamberger, J. 1967. Environment and cultural classification: a study of the northern Cayapo. Ph.D. Dissertation. Department of Anthropology, Harvard University.

. 1979. Exit and voice in Central Brazil: the politics of flight in Kayapó society. In Maybury-Lewis, D. (ed) Dialectical societies. Cambridge, MA: Harvard University Press. Pp. 130-145.

Blunt, A. 2007. Cultural geographies of migration: mobility, transnationality and diaspora. Progress in Human Geography 31: 684-694.

Burke, B.J. 2012. Transforming power in Amazonian extractivism: historical exploitation, contemporary "fair trade", and new possibilities for indigenous cooperatives and conservation. Journal of Political Ecology 19: 114-126.

Bourdieu, P. 1990. The logic of practice. Richard Nice, transl. Stanford, CA: Stanford University Press.

Brody, H. 1985. Maps and dreams: Indians and the British Columbian frontier. London: J. Norman and Hobhouse.

Castree, N. 2006. From neoliberalism to neoliberalisation: consolations, confusions, and necessary illusions. Environment and Planning A 38: 1-6. draft 
. 2008. Neoliberalising nature: the logics of deregulation and reregulation. Environment and Planning A 40(1): 131-152.

Conklin, B. 1997. Body paint, feathers, and VCRs: aesthetics and authenticity in Amazonian activist. American Ethnologist 24(4): 711-737.

Conklin, B. and L. Graham. 1995. The shifting middle ground: Amazonian Indians and eco-politics. American Anthropologist 97(4): 695-710.

Cresswell, T. 2004. Place: a short introduction. Malden, MA: Blackwell Publishing.

Diamant, A. 2010. Brazil's emerging sectoral framework for reducing emissions from deforestation and degradation and the potential to deliver greenhouse gas emissions reductions from avoided deforestation in the Amazon's Xingu River Basin. 1021606 Technical Update. Palo Alto, CA: Electric Power Research Institute.

Dove, M. 2011. The banana tree at the gate a history of marginal peoples and global markets in Borneo. New Haven: Yale University Press.

Escobar, A. 2001. Culture sits in places: reflections on globalism and subaltern strategies of localisation. Political Geography 20:139-174.

- 2008. Territories of difference: place, movements, life, redes. Durham: Duke University Press.

Ewart, E. 2003. Lines and circles: images of time in a Panará village. Journal of the Royal Anthropological Institute 9(2):261-279.

Feather, C. 2009. The restless life of the Nahua: shaping people and places in the Peruvian Amazon. In M. N. Alexiades (ed.) Mobility and migration in Indigenous Amazonia: contemporary ethnoecological perspectives. New York: Bergham Books. Pp. 86-96.

Feld, S. and K. Basso (eds.) 1996. Senses of place. Santa Fe: School of American Research Press.

Fine-Dare, K. and S. L. Rubenstein, eds. 2009. Border crossings: transnational Americanist anthropology. Lincoln: University of Nebraska Press.

Fisher, W. 1991. Dualism and its discontents: social process and village fissioning among the Xikrin Kayapó of Central Brazil. Ph.D. dissertation, Department of Anthropology, Cornell University.

-1994. Megadevelopment, environmentalism and resistance: the institutional context of Kayapó Indigenous politics in Central Brazil. Human Organization 53(3): 220-232.

-1998. The teleology of kinship and village formation: community, ideal and practice among the Northern Gê of Central Brazil. South American Indian Studies 5: 52-59.

Foucault, M. 1980. Questions on geography. In C. Gordon (ed.) Power/Knowledge. New York: Pantheon. Pp. 63-77.

Gross, D. 1975. Protein capture and cultural development in the Amazon Basin. American Anthropologist 77(3): 526-549.

Guha, R. 2000. The unquiet woods: ecological change and peasant resistance in the Himalaya. Berkeley: University of California Press.

Gupta, A and J. Ferguson (eds.) 1997. Culture, power, place: explorations in critical anthropology. Durham: Duke University Press.

Hannerz, U. 1997. Fluxos, fronteiras, híbridos: palavras-chave da antropologia transnacional. Mana 3(1): 739.

Harvey, D. 1990. The condition of postmodernity: an enquiry into the origins of cultural change. Oxford: Blackwell.

Hecht, S. 2011. The new Amazon geographies: insurgent citizenship, "Amazon Nation" and the politics of environmentalisms. Journal of Cultural Geography 28(1): 203-223.

Heidegger, M. 1971. Poetry, language, thought. A. Hofstadter, transl. New York: Harper Colophon Books.

Hirsch, E., and E. O'Hanlon (eds.) 1995. The anthropology of landscape: perspectives on place and space. Oxford: Clarendon Press.

Ingold, T. 1993a. Globes and spheres: the topology of environmentalism. In K. Milton (ed.) Environmentalism: the view from anthropology. London: Routledge. Pp. 31-42. 
1993b. Temporality of the landscape. World Archaeology 25(2): 152-174.

2011. Being alive: essays on movement, knowledge and description. London: Routledge.

Kahn, M. 2000. Tahiti intertwined: ancestral land, tourist postcard, and nuclear test site. American Anthropologist 102:7-26.

Lauer, M. and S. Aswani. 2009. Indigenous ecological knowledge as situated practices: understanding fishers' knowledge in the Western Solomon Islands. American Anthropologist 111: 317-329.

Lea, V. 1986. Nomes e nekrets Kayapó: uma concepção de riqueza. Ph.D. dissertation, Department of Anthropology, Universidade Federal do Rio de Janeiro.

1992. Mebengokre (Kayapó) onomastics: a facet of houses as total social facts in Central Brazil. Man, New Series 27(1):129-153.

—.1995. The houses of the Mebengokre (Kayapó) of Central Brazil: a new door to their social organization. In J. Carsten and S. Hugh-Jones (ed.) About the house. Cambridge: University Press. Pp. 206-225.

2001. The composition of Mebengokre (Kayapó) households in Central Brazil. In L.M. Rival and N. Whitehead (eds.) Beyond the visible and the material: the Amerindianization of society in the work of Peter Riviére. Oxford: Oxford University Press. Pp. 157-176.

Lefebvre, H. 1991 (1974). The production of space. Oxford, UK: Blackwell.

Little, P. 2001. Amazonia: territorial struggles on perennial frontiers. Baltimore, MD: The Johns Hopkins University Press.

Low, S.M. and D. Lawrence-Zúñiga. 2003. Locating culture. In S.M. Low and D. Lawrence-Zúñiga (eds.). The anthropology of space and place: locating culture. Malden, MA: Blackwell. Pp. 1-48.

Massey, D. 2005. For space. London: Sage Publications.

Murphy, I. 2004. And I, in my turn, will pass it on: knowledge transmission among the Kayapó. Dallas: SIL International.

Nadasdy, P. 2004. Hunters and bureaucrats: power, knowledge, and Aboriginal-state relations in the Southwest Yukon. Seattle: University of Washington Press.

Naughton-Treves, L., M.B. Holland, and K. Brandon. 2005. The role of protected areas in conserving biodiversity and sustaining local livelihoods. Annual Review of Environment and Resources 30: 219252.

Niezen, R. 2003. The origins of indigenism: human rights and the politics of identity. Berkeley: University of California Press.

Nuttall, M. 1998. Protecting the Arctic: Indigenous people and cultural survival. Amsterdam: Harwood Academic Publishers.

Ortner, S.B. 2006. Anthropology and social theory: culture, power, and the acting subject. Durham: Duke University Press.

Peet, R. and M.J. Watts. 1996. Liberation ecologies: environment, development, social movements. New York: Routledge. Ch.1

Peluso, N. L. 1992. Rich forests, poor people: resource control and resistance in Java. Berkeley: University of California Press.

Peluso, N. L. and M.J. Watts (eds.) 2001. Violent environments. Ithaca, NY: Cornell University Press.

Posey, D. 2002. Kayapó ethnecology and culture. K. Plenderleith (ed. posthumously). London: Routledge.

Rabben, L. 2004. Brazil's Indians and the onslaught of civilization: the Yanomami and the Kayapó. Seattle: University of Washington Press.

Ramos, A. 1998. Indigenism: ethnic politics in Brazil. Madison: University of Wisconsin Press.

Relph, E. 1976. Place and placelessness. London: Pion.

Rival, L.M. 2002. Trekking through history: the Huaorani of Amazonian Ecuador. New York: Columbia

University Press.

Rival, L.M. 2005. Amazonian historical ecologies. Journal of the Royal Anthropological Institute 12 (S1): S79-S94. 
Robbins, P. 2012. Political ecology: a critical introduction. Sussex: Wiley Blackwell.

Rubenstein, S. 2004. Steps to a political ecology of Amazonia. Tipití 2(2): 131-176.

Santos-Granero, F. 1998. Writing history into the landscape: space, myth, and ritual in contemporary Amazonia. American Ethnologist 25(2): 128-148.

- 2006. Sensual vitalities: noncorporeal modes of sensing and knowing in Native Amazonia. Tipití 4(1): 57-80.

Sassen, S. (ed.) 2002. Global networks, linked cities. New York: Routledge.

Schama, S. 1995. Landscape and memory. London: Harper Collins.

Schmink, M. and C.H. Wood (eds.) 1992. Contested frontiers in Amazonia. New York: ColumbiaUniversity Press.

Schwartzman, S., A. Alencar, H. Zarin and A.P. Santos Souza. 2010. Social movements and large-scale tropical forest protection on the Amazon Frontier: conservation from chaos. The Journal of Environment and Development 19(3): 274-299.

Seeger, A. 1981. Nature and society in Central Brazil: the Suya Indians of Mato Grosso. Cambridge: Harvard University Press.

Soja, E. 1996. Thirdspace: journeys to Los Angeles and other real-and-imagined places. Oxford: Blackwell.

Snead, J. E., C. Erikson and J. A. Darling (eds.) 2009. Landscapes of movement: trails, paths and roads in anthropological perspective. Philadelphia: University of Pennsylvania Museum of Archaeology and Anthropology.

Spoon, J. 2011. The heterogeneity of Khumbu Sherpa ecological knowledge and understanding in Sagarmatha (Mount Everest) National Park and Buffer Zone, Nepal. Human Ecology 39: 657-672.

Stocks, A. 2005. Too much for too few: problems of Indigenous Land Rights in Latin America. Annual Review of Anthropology 34 (1): 85-104.

Tilley, C. 1994. A phenomenology of landscape: places, paths, and monuments. Oxford: Berg Publishers.

Tsing, A. 2003. Cultivating the wild: honey-hunting and forest management in Southeast Kalimantan. In C. Zerner (ed.) Culture and the question of rights: forests, coasts, and seas in Southeast Asia. Durham: Duke University Press. Pp. 24-55.

- 2005. Friction: an ethnography of global connection. Princeton: Princeton University Press. 2007. Indigenous voice. In M. de la Cadena and O. Stark (eds.) Indigenous experience today. Oxford: Berg. Pp.33-68.

Tuan, Y.-F. 1977. Space and place: the perspective of experience. Minneapolis: University of Minnesota Press.

Turner, T. 1966. Social structure and political organization among the Northern Cayapo. Ph.D. dissertation. Department of Anthropology, Harvard University.

—. 1979. Kinship, household, and community structure among the Kayapó. In D. Maybury-Lewis (ed.) Dialectical societies. Cambridge: Harvard University Press. Pp. 179-217.

- 1980. The social skin. In J. Cherfas and R. Lewin (eds.) Not work alone: a cross-cultural study of activities superfluous to survival. Beverley Hills, CA: Temple Smith. Pp. 111-140.

- 1995a. An indigenous people's struggle for socially equitable and ecologically sustainable production: the Kayapó revolt against extractivism. Journal of Latin American Anthropology 1(1): 98-121.

- 1995b. Social body and embodied subject: bodiliness, subjectivity, and sociality among the Kayapó. Cultural Anthropology 10(2):143-170.

- 2001. The Kayapo resistance. In J. Spradley and D.W. McCurdy (eds.) Conformity and conflict: readings in cultural anthropology. Boston: Allyn and Bacon. Pp. 368-385.

- 2003. The beautiful and the common: inequalities of value and revolving hierarchy among the Kayapó. Tipití 1:11-26.

Urry, J. 2007. Mobilities. Cambridge: Polity Press. 
Verswijver, G. 1985. Considerations on Mekrãgnoti warfare. Ph.D. dissertation. Doctor in de Sociale Wetenschappen Facultei van Rechtsgeleerdheit: Rijksuniversiteit, Gent.

. 1992a. Between village and forest. In G. Verswijver (ed) Kaiapó Amazonia: the art of body decoration. Royal Museum for Central Africa: Snoeck-Ducaju \& Zoon. Pp. 11-26.

- 1992b. The club-fighters of the Amazon: warfare among the Kaiapo Indians of Central Brazil. Gent: Rijksuniversiteit te Gent.

Warren, K. and J.E. Jackson (eds.). 2003. Indigenous movement, self-representation, and the state in Latin America. Austin: University of Texas Press.

Werner, D. 1983. Why do the Mekranoti trek? In R. Hames and W. Vickers (eds.) Adaptive responses of Native Amazonians. New York: Academic Press. Pp. 225-238.

West, P. 2006. Conservation is our government now: the politics of ecology in Papua New Guinea. Durham: Duke University Press.

West, P., J. Igoe, and D. Brockington. 2006. Parks and peoples: the social impact of protected areas. Annual Review of Anthropology 35: 251-277.

Whitridge, P. 2004. Landscapes, houses, bodies, things: "place" and the archaeology of Inuit imaginaries. Journal of Archaeological Method and Theory 11(2): 213-250. $\underline{\mathrm{draft}}$

Zanotti, L. 2009. Economic diversification and sustainable development: the role non-timber forest products play in the monetization of Kayapó livelihoods. Journal of Ecological Anthropology 13: 26-41.

Zimmerman, B., C. A. Peres, J. R. Malcolm, and T. Turner. 2001. Conservation and development alliance with the Kayapó of South-Eastern Amazonia, a tropical forest Indigenous People. Environmental Conservation 28(1): 10-22. 